\title{
Effects of Soil Compaction and Relative Light Intensity on Survival and Growth Performance of Planted Shorea macrophylla (de Vriese) in Riparian Forest along Kayan Ulu River, Sarawak, Malaysia
}

\author{
Aina Nadia Najwa Mohamad Jaffar $\mathbb{D}^{1},{ }^{1}$ Mohd Effendi Wasli, ${ }^{1}$ Mugunthan Perumal $\mathbb{D},{ }^{1}$ \\ Jonathan Lat, ${ }^{2}$ and Hamsawi Sani ${ }^{1}$ \\ ${ }^{1}$ Faculty of Resource Science and Technology, Universiti Malaysia Sarawak, 94300 Kota Samarahan, Sarawak, Malaysia \\ ${ }^{2}$ Forest Department of Sarawak, Wisma Sumber Alam Petra Jaya, 93660 Kuching, Sarawak, Malaysia
}

Correspondence should be addressed to Aina Nadia Najwa Mohamad Jaffar; ainanadianajwamj94@gmail.com

Received 12 January 2018; Revised 5 July 2018; Accepted 29 July 2018; Published 19 August 2018

Academic Editor: Qing-Lai Dang

Copyright (c) 2018 Aina Nadia Najwa Mohamad Jaffar et al. This is an open access article distributed under the Creative Commons Attribution License, which permits unrestricted use, distribution, and reproduction in any medium, provided the original work is properly cited.

\begin{abstract}
A study was conducted in riparian forest along Kayan Ulu River, Sarawak, Malaysia, to investigate the effects of soil compaction and relative light intensity (RLI) on survival and growth performance of planted Shorea macrophylla. The study sites were stands reforested in different years (1996: SPD96; 1997: SPD97; 1998: SPD98; 1999: SPD99). The survival, growth performance, soil compaction, and RLI were measured. SPD96 trees had the highest survival (84\%) and showed the most favourable growth. Average height, mean annual increment in height, and RLI were highest in SPD97 while mean annual increment in volume was highest in SPD98. Soil compaction in SPD98 and SPD99 was higher as compared to SPD96 and SPD97. This was due to the compacted soils caused by anthropogenic activities and natural causes (wet soils) in riparian forest along Kayan Ulu River at shallow depth. High survival and favourable growth performance of $S$. macrophylla were influenced by the edaphic factor with special reference to less compacted soils and high RLI. Stepwise multiple regression demonstrated significant effects of soil penetration resistance at the depth of $0-30 \mathrm{~cm}$ and RLI on mean annual increment in diameter. Further ecological studies on other environmental factors should be implemented to draw up a Dipterocarp planting scheme for the future restoration of riparian ecosystem.
\end{abstract}

\section{Introduction}

Southeast Asia's tropical rainforest which includes a portion of Borneo Island is considered as one of the world's biodiversity hotspots [1]. However, the richness of species in the tropical rainforest is undergoing disturbance due to the overexploitation of forest resources for various land uses such as shifting cultivation, conversion for lands to agriculture, illegal logging activities, and clearance of forest area for development purposes. Collectively these extinction instances of endangered species, disruption in the carbon cycle which might lead to global climate change, expansion of degraded lands, and reduction of soil productivity may negatively affect the ecological health of the tropical forest [2] .
Considering such a situation, it is crucial to conserve forest resources in a sustainable manner [3]. Efforts such as reforestation program by enrichment planting in the State of Sarawak, Malaysia, have been established by the Forest Department of Sarawak in collaboration with the international non-governmental organizations (NGOs) from Japan. Reforestation via plantation forestry through the planting of high-quality indigenous species such as Dipterocarps is considered as one of the ways to recover the original forest ecosystem [4]. The success of reforestation depends largely on factors such as soil conditions in the area, optimum sunlight exposure, water quality, and regulation of climate. Enrichment planting is the most common technique used on degraded forests without eliminating the existing valuable 
species [5]. Its effectiveness can be measured by tree growth performance and survival.

Soils are essential sources in wide diversity of ecosystem services that are affected greatly by the impacts given to the forest. Direct effects include those typically associated with soil physical disturbances in impervious surfaces considered as potential diagnostic properties [6,7]. Soil compaction measurement is quite recommendable for the comprehensive understanding of the soil-related topic with respect to the environmental conditions prevailing in degraded tropical forests [6]. Dinis et al. [7] reported that as soils become increasingly compacted, respiration of roots shifts toward an anaerobic state which may lead to the inhibition growth of plants. In addition to that, accumulation of stagnant water may also lead to limiting support for root respiration where limited oxygen is available during anaerobic respiration $[8,9]$. The longer the trees being submerged in water, the greater the potential for tree-induced injury. However, in our recent study it was stated that the root of S. macrophylla trees was able to survive and grow under waterlogged soil conditions with a low availability of oxygen [10]. Thus, S. macrophylla not only is considered as shade tolerant species but also can be considered as flood tolerant tree $[10,11]$.

Several studies have been reported on reforestation activities using indigenous tree species with various planting techniques for rehabilitating degraded land areas [12-14]. In Sarawak, studies have been conducted to understand the ecological aspects of restoration in tropical rainforests on an experimental basis by us [10] and by others [15-18]. According to Hattori et al. [14] in Sarawak, the monitoring of environmental conditions including soil compaction and RLI is crucial for Dipterocarp survival on degraded land. These two factors in long-term monitoring had been considered as integrated evaluations of external effects that lead to variation in survival and growth performance of planted Dipterocarp trees.

Previous studies from our group $[10,11,15]$ and others $[6,16-18]$ starting in the year 1999 have emphasized determining suitable species for enrichment planting in relation to the growth performance, planting techniques, and soil characteristics. Thus, this study was conducted due to a gap in the information available on the potential of indigenous tree species after enrichment planting for restoration ecology in riparian areas. Even within a single area, the environmental factors may vary widely due to the spatial variability. Therefore, a study on the effects of environmental factors on survival and growth of planted S. macrophylla (de Vriese) is essential for future conservation strategies along the riparian areas. The objective of this study was thus to investigate the effects of soil compaction and relative light intensity on the productivity of $S$. macrophylla (de Vriese) in the riparian forest along Kayan Ulu River, Sarawak, Malaysia.

\section{Materials and Methods}

2.1. Information on the Reforestation Sites. This assessment was conducted in riparian forest at Sampadi Forest Reserve (N01 $34^{\prime} 13^{\prime \prime}$, E109 $53^{\prime} 12^{\prime \prime}$ ) which is along Kayan Ulu River, Lundu, Sarawak, and is approximately $72 \mathrm{~km}$ from the city of Kuching (Figure 1) [19, 20]. The average annual rainfall in the study area was $3361 \mathrm{~mm}$ with minimum of $1799 \mathrm{~mm}$ and maximum of $4765 \mathrm{~mm}$; meanwhile, annual temperatures range from $23^{\circ} \mathrm{C}$ to $33^{\circ} \mathrm{C}[21,22]$. The soil type in the study area comprised combination of sandstone, coarse-grained, humult Ultisols, and sandy residual parent material which corresponds to Ultisols soil order based on Soil Taxonomy Classification [10, 11, 20, 23]. Based on the USDA-NRCS Soil Taxonomy Classification System, the soil group corresponds to Typic Paleaquults [10, 11, 20]. According to Sarawak Soil Classification System, the soil in the study area was classified as Grey-White Podzolic soil groups $[10,11,20]$. The general soil physicochemical properties in the study sites were acidic, with $\mathrm{pH}\left(\mathrm{H}_{2} \mathrm{O}\right)$ values less than $5.50[10,11,20]$. The significant characteristics of the soils in the study area could be considered with low nutrient status of nitrogen $(\mathrm{N})$, phosphorus $(\mathrm{P})$, and potassium $(\mathrm{K})$ as well as poor in exchangeable bases including calcium $(\mathrm{Ca})$, magnesium $(\mathrm{Mg})$, and sodium $(\mathrm{Na})$ at both surface and subsurface soil layers [11, 23].

According to Forest Department of Sarawak, the original vegetation at Sampadi Forest Reserve consisted of a Lowland Mixed Dipterocarp Forest, Riparian Forest, and Kerangas Forest $[11,24]$. The reforestation sites were previously loggedover in the past 40 years (since years 1970-1980s) and most of the forests have lost their original soils structure. S. macrophylla had been planted in reforestation sites at different age stands for conservation purpose. Based on in situ observation, the common pioneer trees species found during site surveys were such genera as Aleurites (Euphorbiaceae), Amomum (Zingiberaceae), Cratoxylum (Clusiaceae), Dillenia (Dilleniaceae), Elaeocarpus (Elaeocarpaceae), Ficus (Moraceae), Hopea (Dipterocarpaceae), Ilex (Aquifoliaceae), Lithocarpus (Fagaceae), Norrisia (Loganiaceae), Pentace (Tiliaceae), Pentaspadon (Anacardiaceae), Sarcotheca (Oxalidaceae), and Vitex (Verbenaceae).

Our previous studies reported that heavy floods occurred almost every year at the study plots resulting in low soil levels of N, P, and K along the riparian forest of Kayan Ulu River, Lundu, Sarawak $[10,11]$. We also suggested that the presence of clay in the study sites contributed to water retention capacity at both surface and subsurface soils due to annual flooding which resulted in shallow rooting depth [20]. Floods break down from the surface soils followed by dispersing the soil particles and minerals associated with them, especially in surface soils (less than $30 \mathrm{~cm}$ ) from the surface.

2.2. Site Preparation and Experimental Design. Six study plots sized $25 \mathrm{~m} \times 25 \mathrm{~m}$ were constructed in each of the four successive years at the reforestation sites (Figure 2). $S$. macrophylla trees were planted between 1996 and 1999 and abbreviated as SPD96, SPD97, SPD98, and SPD99. There were 25 trees per plot in six plots for a total of 150 trees per year. The four study sites cover an area of 1.5 hectares. Thus, the total stand density of the area was 400 trees per hectare. Briefly, seedlings were raised and cultivated for a year in the nursery and transplanted during a community reforestation project in $1996,1997,1998$, and 1999. At these reforestation sites, the tree seedlings were planted under line planting technique with lines cut $5 \mathrm{~m}$ apart and trees planted at $5 \mathrm{~m}$ interval along 


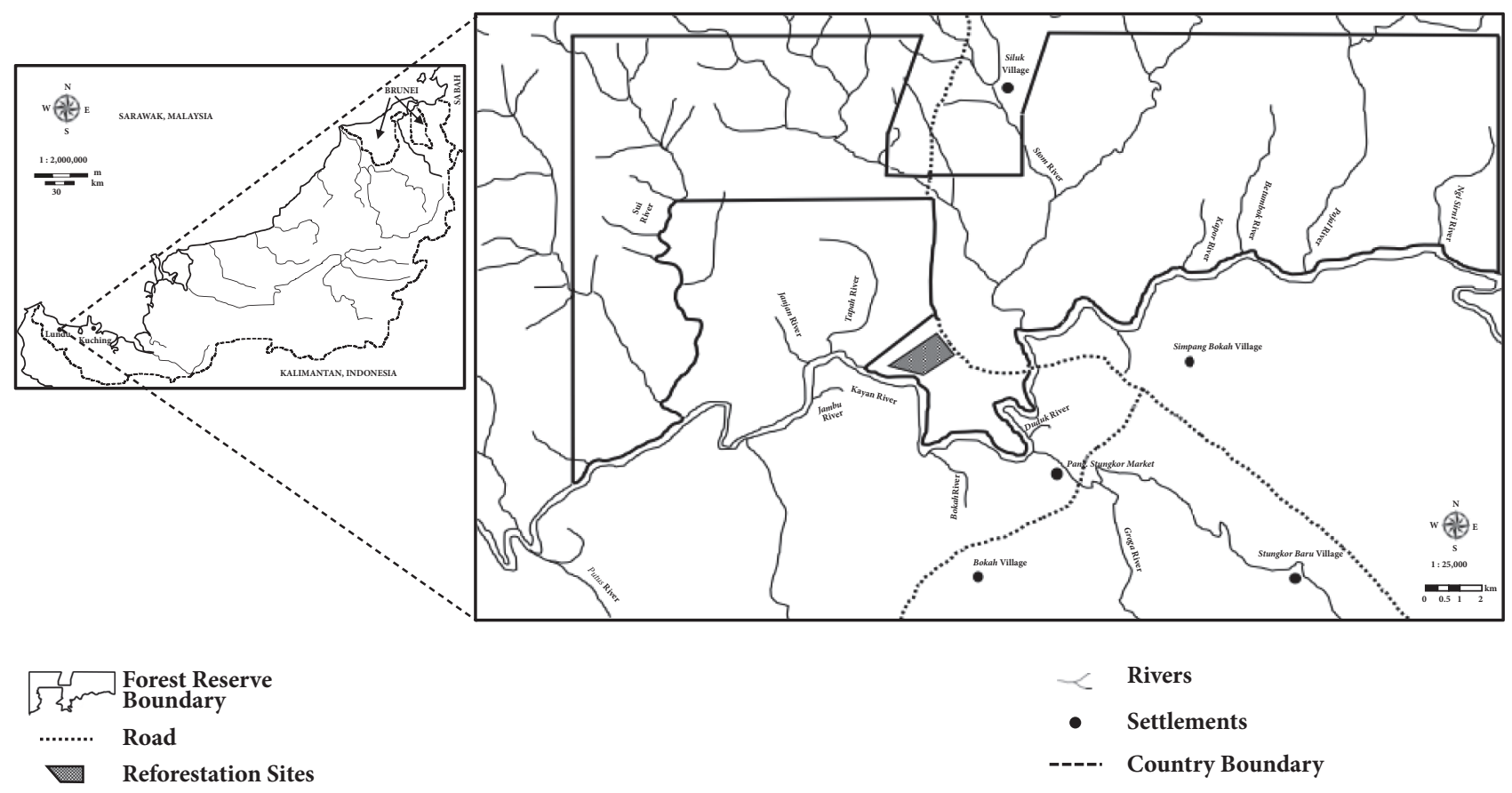

FIgURE 1: Location of the study area: Sampadi Forest Reserve, Lundu, Sarawak. Perumal et al.; Department of Agriculture, Sarawak, Malaysia $[11,19]$.

the lines. Preparation and maintenance of planting lines were conducted by manual slashing along the lines once a year. Large pioneer tree species in the reforestation sites were left uncut during the maintenance activities [11, 20].

2.3. Survival and Growth Performance Measurements. Field assessments on the survival and growth performance of planted trees were carried out from June to September 2016. This study was the reassessment from our previous work in the same study sites conducted in the year 2013 and published in the year 2017 [10]. The following formula was used to calculate the survival of planted S. macrophylla [10]:

$$
X=\frac{Z}{Y} \times 100 \%
$$

\section{$\mathrm{X}$ is survival of planted S. macrophylla}

$\mathrm{Y}$ is total planted S. macrophylla

$\mathrm{Z}$ is total planted S. macrophylla alive in 2016

The total and merchantable tree heights were measured by using either a Suunto clinometer or a pole with scale. Trigonometry principle was used to obtain the height by measuring the angles from the horizontal to the tip of the tree and to the base of the tree. The diameter at breast height $(\mathrm{DBH})$ of planted trees was measured using diameter tape and taken at $1.3 \mathrm{~m}$ from the ground level. The stand volumes of planted S. macrophylla in all study plots surveyed were calculated. The mean annual increment in tree height (MAIH), diameter at breast height (MAID), and volume (MAIV) were recorded.
2.4. Measurement of Soil Compaction and Relative Light Intensity (RLI). Soil compaction was measured from the soil surface to $100 \mathrm{~cm}$ depth, at 96 random points for all the four study sites. As in Asaoka and Masaoka [25], the apparatus consisted of a moisture probe to determine moisture content attached to a cone penetrometer [Hasegawa-Type Cone Penetrometer (Daito Techno Green Co., Tokyo, H-60)] with a $60^{\circ}$ bit. A weight of $2.0 \mathrm{~kg}$ was dropped onto the apparatus from a height of $50 \mathrm{~cm}$ (after removing the litter layer, twigs, and root fragments) and without causing significant disturbance to the plant stands. The number of strikes required to drive starting from $0 \mathrm{~cm}$ of the penetrometer continuously up to $100 \mathrm{~cm}$ depth was used as a measure of soil compaction $[6,26]$. A knocking head drove the cone into the soil. The total number of strikes was counted to $10 \mathrm{~cm}$ interval depth and the soil penetration resistance was calculated by the following formula:

$$
\mathrm{E}=\mathrm{M} \times \mathrm{G} \times \mathrm{H} \times \mathrm{C}
$$

where $\mathrm{E}$ is the soil penetration resistance $(\mathrm{J}), \mathrm{M}$ is the mass of the penetrometer $(2.0 \mathrm{~kg}), \mathrm{G}$ is the gravitational acceleration $\left(9.8 \mathrm{~m} \mathrm{~s}^{-2}\right), \mathrm{H}$ is the vertical drop of the penetrometer weight $(0.5 \mathrm{~m})$, and $\mathrm{C}$ is the count of strikes for each depth [6, 25]. Average soil compaction expressed in soil penetration resistance was examined from the depth of $0-30 \mathrm{~cm}$ (surface soils) and 30-100 cm (subsurface soils) in 96 random points.

RLI was recorded in September 1-14, 2016, under standardized conditions at $130 \mathrm{~cm}$ above ground level during a cloudy day using an Extech 401025 Digital Light Meter [Lux/Foot-Candle (FC)] meters with 0-2000 Foot-Candle (FC) range $[18,27]$. In the year 2016, the RLI measurements of 


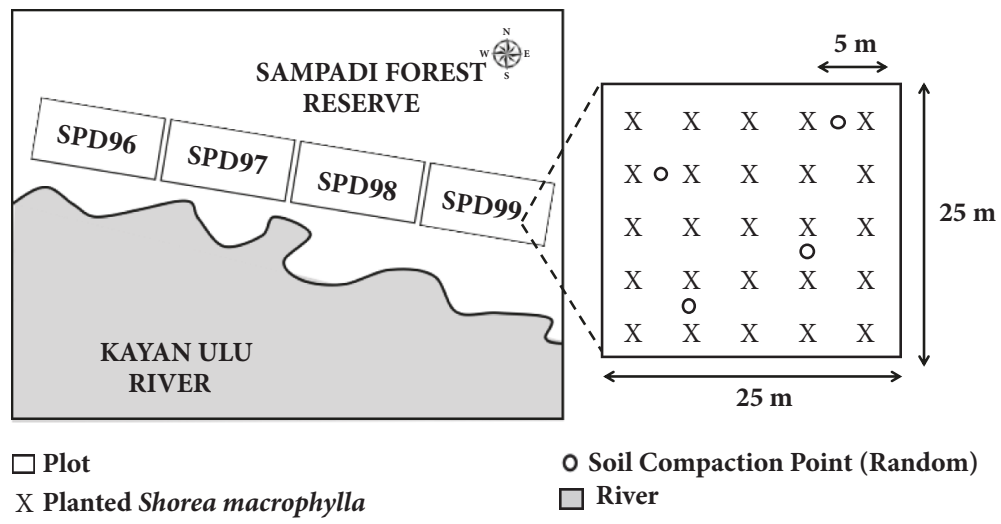

FIGURE 2: Planting design within reforestation sites showing the main plots (six random replications in each main plot), planting distance, and planting direction.

TABLE 1: Survival of planted S. macrophylla in plot aged 20 years (SPD96), plot aged 19 years (SPD97), plot aged 18 years (SPD98), and plot aged 17 years (SPD99).

\begin{tabular}{lcc}
\hline Study Plot & Year of Tree Planted & Survival (\%) \\
\hline SPD96 & 1996 & $84.0 \mathrm{~b}$ \\
SPD97 & 1997 & $77.0 \mathrm{~b}$ \\
SPD98 & 1998 & $70.0 \mathrm{ab}$ \\
SPD99 & 1999 & $55.0 \mathrm{a}$ \\
\hline
\end{tabular}

Means: values in the same column followed by different letters indicate significant differences among sites at $P<0.05$ using Tukey's test.

the experimental plots were measured 25 times in each $25 \mathrm{~m}$ $\times 25 \mathrm{~m}$ plot. In sum, $600 \mathrm{RLI}$ readings from the four main study plots were recorded. Open space light intensity was measured outside the reforestation sites in order to compare the light intensity in every single tree at the planted area with the open space area. The unit of Foot-Candle was converted into Microeinstein to obtain light percentage according to the formula below $[18,27]$ :

$$
\mathrm{P}=\frac{\mathrm{Q}(\mathrm{FC} \mathrm{X} \mathrm{0.2)}}{\mathrm{R}} \times 100
$$

$\mathrm{P}$ is percentage of light intensity under each tree

$\mathrm{Q}$ is light intensity in Foot-Candle (FC)

$\mathrm{R}$ is open space light intensity

FC $\times 0.2$ is used to convert Foot-Candle unit to Microeinstein

2.5. Statistical Analyses. Differences between MAIH, MAID, MAIV, and RLI values in all study sites were analyzed by using one-way Analysis of Variance (ANOVA). Scheffe's test as post hoc test was used to compare the survival and growth performance from each plot. The data on soil penetration resistance was statistically analyzed by using Tukey's test to compare significant differences between the planting years. SPSS version 17.0 for Windows was used to compare the survival and growth performance of planted S. macrophylla. Data on the descriptive statistics (mean) were analyzed by using MINITAB 14.0 for Windows. Stepwise multiple regression analysis was performed to determine the effects of selected environmental factors, namely, soil compaction and RLI, on survival and growth. In the regression analysis, soil penetration resistance and RLI for both surface (0$30 \mathrm{~cm}$ depth) and subsurface soils (30-100 cm depth) acted as explanatory variables. Percentage of survival and tree growth parameters, including MAIH, MAID, and MAIV, acted as dependent variables.

\section{Results and Discussion}

3.1. Survival and Growth Performance. The survival percentage of planted S. macrophylla at various age stands is shown in Table 1 and increased with age ranging from 84\% in SPD96 to $55 \%$ in SPD99. These results were similar to those trends in our 2017 study [10]. However, survival within each plot in this study was lower compared to the previous studies. Currently, SPD97 and SPD98 show 77\% and 70\% survival, respectively. Based on field observations, the presence of stagnant water after heavy precipitation during the rainy season and annual flooding may alter the survival of planted S. macrophylla (Figure 3) [10]. Dipterocarp species such as Shorea spp. in Southeast Asia shows relatively high mortality rates ranging from $20 \%$ to $50 \%$ in the first year of assessment and sometimes even higher, in which the attainment is high for the older trees $[28,29]$.

Figures 4(a) and 4(b) show the average height and $\mathrm{DBH}$ of S. macrophylla trees. The average height ranged from $15.99 \mathrm{~m}$ in SPD99 to $20.57 \mathrm{~m}$ in SPD97. SPD96 and SPD98 average tree height were intermediate at $18.63 \mathrm{~m}$ and $16.11 \mathrm{~m}$, respectively. The average $\mathrm{DBH}$ was $16.7 \mathrm{~cm}, 12.8 \mathrm{~cm}, 8.8 \mathrm{~cm}$, and $8.1 \mathrm{~cm}$ in SPD96, SPD97, SPD98, and SPD99, respectively. 
TABLE 2: Mean annual increments of height (MAIH), diameter at breast height (MAID), and volume (MAIV) of planted Shorea macrophylla in reforestation sites.

\begin{tabular}{lccccc}
\hline Variables & Unit & $\begin{array}{c}\text { SPD96 } \\
(\mathbf{2 0} \text { years-old }) \\
(\mathbf{n = 1 2 6})\end{array}$ & $\begin{array}{c}\text { SPD97 } \\
(\mathbf{1 9} \text { years-old }) \\
(\mathbf{n}=\mathbf{1 1 6})\end{array}$ & $\begin{array}{c}\text { SPD98 } \\
(\mathbf{1 8} \text { years-old }) \\
(\mathbf{n}=\mathbf{1 0 5})\end{array}$ & $\begin{array}{c}\text { SPD99 } \\
(\mathbf{1 7} \text { years-old }) \\
(\mathbf{n}=\mathbf{5 5})\end{array}$ \\
\hline MAIH & $\mathrm{m} \mathrm{year}^{-1}$ & $0.91 \pm 0.04 \mathrm{ab}$ & $1.09 \pm 0.07 \mathrm{~b}$ & $0.85 \pm 0.05 \mathrm{a}$ & $0.94 \pm 0.06 \mathrm{ab}$ \\
MAID & $\mathrm{cm} \mathrm{year}^{-1}$ & $0.83 \pm 0.04 \mathrm{c}$ & $0.67 \pm 0.03 \mathrm{~b}$ & $0.49 \pm 0.03 \mathrm{a}$ & $0.48 \pm 0.03 \mathrm{a}$ \\
MAIV & $\mathrm{m}^{3} \mathrm{ha}^{-1}$ year $^{-1}$ & $0.016 \pm 0.002 \mathrm{~ns}$ & $0.011 \pm 0.002 \mathrm{~ns}$ & $0.021 \pm 0.011 \mathrm{~ns}$ & $0.008 \pm 0.006 \mathrm{~ns}$ \\
\hline
\end{tabular}

Means \pm standard error: values in the same row followed by different letters indicate significant differences among sites at $P<0.05$ using Scheffe's test; ns: no significant differences.

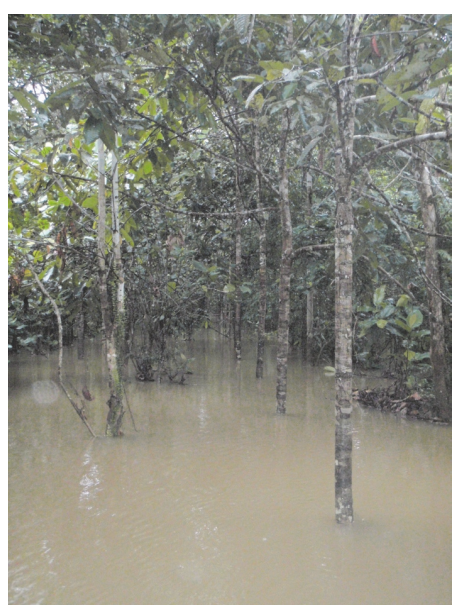

Figure 3: Image of annual flooding at Sampadi Forest Reserve, Lundu, Sarawak reforestation sites.

This order also held for average volume with values of $4.93 \mathrm{~m}^{3}$ $\mathrm{ha}^{-1}, 3.30 \mathrm{~m}^{3} \mathrm{ha}^{-1}, 1.13 \mathrm{~m}^{3} \mathrm{ha}^{-1}$, and $1.26 \mathrm{~m}^{3} \mathrm{ha}^{-1}$. Our current study showed favourable growth performance of $S$. macrophylla in all study plots compared to the distribution of average tree height and DBH in rehabilitated forest stated by Jui et al. [30] were mostly $S$. macrophylla aged 19 years with the value of $9.30 \mathrm{~m}$ and $8.16 \mathrm{~cm}$, respectively.

The growth pattern of planted S. macrophylla was examined in terms of MAIH, MAID, and MAIV (Table 2). The results show that the average values of MAIH ranged from a high value of $1.09 \mathrm{~m} \mathrm{year}^{-1}$ in SPD97, followed by SPD99 $\left(0.94 \mathrm{~m} \mathrm{year}^{-1}\right)$ and SPD96 $\left(0.91 \mathrm{~m} \mathrm{year}^{-1}\right)$, to a low value of $0.85 \mathrm{~m} \mathrm{year}^{-1}$ in SPD98. The MAID average of SPD96 was significantly higher than SPD97 with $0.83 \mathrm{~cm}_{\text {year }}{ }^{-1}$ and $0.67 \mathrm{~cm}_{\text {year }}{ }^{-1}$, respectively, followed by SPD $98(0.49 \mathrm{~cm}$ year $\left.^{-1}\right)$ and SPD99 $\left(0.48 \mathrm{~cm}_{\text {year }}{ }^{-1}\right)$. The average values of MAIV in SPD96 $\left(0.016 \mathrm{~m}^{3} \mathrm{ha}^{-1}\right.$ year $\left.^{-1}\right)$ was higher than SPD98 $\left(0.021 \mathrm{~m}^{3} \mathrm{ha}^{-1}\right.$ year $\left.^{-1}\right)$ followed by SPD97 $\left(0.011 \mathrm{~m}^{3}\right.$ $\mathrm{ha}^{-1}$ year $\left.^{-1}\right)$ and SPD99 $\left(0.008 \mathrm{~m}^{3} \mathrm{ha}^{-1}\right.$ year $\left.^{-1}\right)$.

3.2. Soil Compaction and Relative Light Intensity (RLI) Conditions. The assessment of soil compaction is essential to measure soil strength in forest management as it reflects the productivity of the forest areas [31]. In general, the soil penetration resistance at the subsurface depth $(30-100 \mathrm{~cm})$ shows no significant difference between SPD96, SPD97, SPD98, and
SPD99, but there was a significant difference at the surface depths of $0-10 \mathrm{~cm}$ and $20-30 \mathrm{~cm}$ in all study plots (Table 3 ). In SPD96, the soil penetration resistance at $0-10 \mathrm{~cm}$ depth shows $2.5 \mathrm{~J} \mathrm{~cm}^{-1}$ and $5.7 \mathrm{~J} \mathrm{~cm}^{-1}$ at $20-30 \mathrm{~cm}$ depth. Meanwhile, in SPD97, the soil penetration resistance for surface soils was $2.5 \mathrm{~J} \mathrm{~cm}^{-1}$ at depth $0-10 \mathrm{~cm}$ and $6.6 \mathrm{~J} \mathrm{~cm}^{-1}$ for subsurface soils at depth $20-30 \mathrm{~cm}$. Soil penetration resistance in SPD98 for surface soils at the depth of $0-10 \mathrm{~cm}$ was $3.7 \mathrm{~J} \mathrm{~cm}^{-1}$, and subsurface soil at the depth of $20-30 \mathrm{~cm}$ was $7.8 \mathrm{~J} \mathrm{~cm}^{-1}$. Soil penetration resistance in SPD99 for surface soils at the depth of $0-10 \mathrm{~cm}$ was $3.4 \mathrm{~J} \mathrm{~cm}^{-1}$ and $7.1 \mathrm{~J} \mathrm{~cm}^{-1}$ for subsurface soils at $20-30 \mathrm{~cm}$ depth. At surface soils $(0-30 \mathrm{~cm}$ depth), the soil penetration resistance was lower than subsurface soils (30$100 \mathrm{~cm}$ depth) in all study plots, perhaps due to their high soil moisture content and anthropogenic activities [32]. Generally, tree roots concentrate at surface layer $(0-30 \mathrm{~cm}$ depth) where a root mat develops then followed by a subsurface layer $(30-100 \mathrm{~cm}$ depth) [33]. Hattori et al. [6] stated that surface soils from 0 to $20 \mathrm{~cm}$ depth at compacted area in 20 years after logging had two to three times more resistance to penetration than in undisturbed soils [6]. Plots with highly compacted areas had higher penetration resistances through all soil depths $(0-60 \mathrm{~cm})$ [6].

Soil penetration resistance at surface soils was lower for SPD96 and SPD97 trees than for SPD98 and SPD99 trees. This indicated that the surface soils in SPD96 and SPD97 were softer than SPD98 and SPD99. Hattori et al. [6] mentioned that, during the early planting period, inhibition of lateral root elongation in high soil penetration resistance increased the mortality rates of Dipterocarp trees. However, S. macrophylla roots have the ability to penetrate the compacted surface soils to access softer subsurface soils beyond $100 \mathrm{~cm}$ in depth if they encounter high soil penetration resistance $[26,34]$. Previous studies showed that tree roots do not have any constraints due to overwetness in study area $[26,34]$. Our study found that high soil penetration resistance is in the range of $50-100 \mathrm{~cm}$ soils depth. This was ascribed to anthropogenic activities including compaction from degraded land and selective logging by the bulldozer based on the history of the forest $[35,36]$. Greacen and Sands [33] reviewed that the causes of forest soil compaction were due to the heavy machine and it affects the soil from the surface to a depth of $30 \mathrm{~cm}$. The soils under a logging road were compacted to a depth of $50 \mathrm{~cm}$ depending on dry or moist soils and the impact of heavy machinery on soils with respect to machinery passes in the field. Batey [37] mentioned that if the surface layers are moist and soft lying over dry 


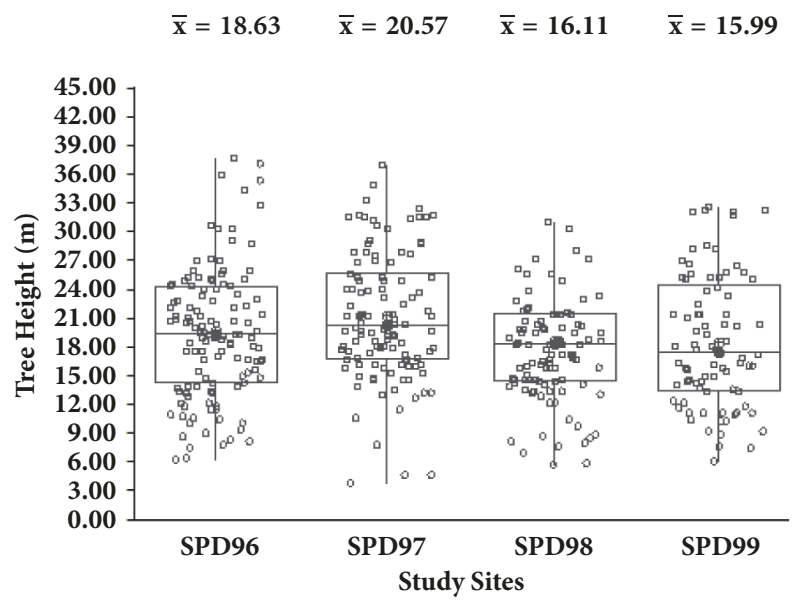

(a)

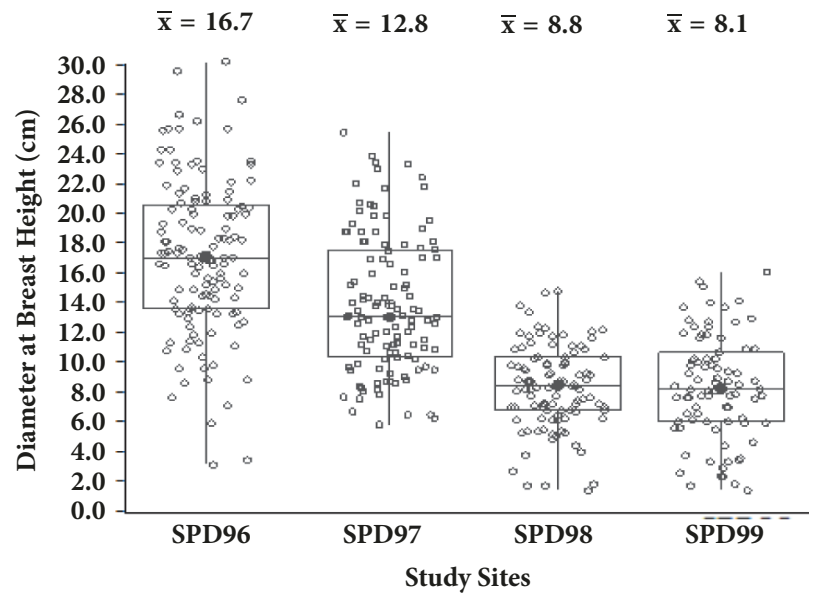

(b)

FIGURE 4: Boxplots: average total height and diameter at breast height of planted S. macrophylla in SPD96, SPD97, SPD98, and SPD99 display individual data points. The boxplots (box and whisker illustrations) display data on values of minimum, maximum, first quartile, third quartile, interquartile range, and median as shown in the figure above. $\overline{\mathrm{x}}$ : mean value; $\mathrm{n}$ : number of survived trees.

TABLE 3: Comparison of soil penetration resistance at 0-100 $\mathrm{cm}$ depth in plot aged 20 years (SPD96), plot aged 19 years (SPD97), plot aged 18 years (SPD98), and plot aged 17 years (SPD99).

\begin{tabular}{|c|c|c|c|c|c|c|c|c|c|c|}
\hline \multirow[b]{2}{*}{ Depth $(\mathrm{cm})$} & \multicolumn{10}{|c|}{ Soil Penetration Resistance $\left(\mathrm{J} \mathrm{cm}^{-1}\right)$} \\
\hline & 0-10 & $10-20$ & $20-30$ & $30-40$ & $40-50$ & $50-60$ & $60-70$ & $70-80$ & $80-90$ & $90-100$ \\
\hline \multicolumn{11}{|l|}{ Study Sites } \\
\hline SPD96 & $2.5 \pm 0.1 \mathrm{a}$ & $4.3 \pm 0.2 \mathrm{~ns}$ & $5.7 \pm 0.4 \mathrm{a}$ & $6.9 \pm 0.7 \mathrm{~ns}$ & $8.6 \pm 0.7 \mathrm{~ns}$ & $11.3 \pm 0.9 \mathrm{~ns}$ & $14.7 \pm 2.2 \mathrm{~ns}$ & $19.3 \pm 3.0 \mathrm{~ns}$ & $21.1 \pm 3.1 \mathrm{~ns}$ & $24.7 \pm 3.6 \mathrm{~ns}$ \\
\hline SPD97 & $2.5 \pm 0.2 \mathrm{a}$ & $4.3 \pm 0.4 \mathrm{~ns}$ & $6.6 \pm 0.4 \mathrm{ab}$ & $8.3 \pm 0.4 \mathrm{~ns}$ & $9.5 \pm 0.4 \mathrm{~ns}$ & $11.4 \pm 0.5 \mathrm{~ns}$ & $13.7 \pm 0.8 \mathrm{~ns}$ & $15.7 \pm 1.1 n s$ & $18.0 \pm 1.4 \mathrm{~ns}$ & $21.6 \pm 1.8 \mathrm{~ns}$ \\
\hline SPD98 & $3.7 \pm 0.4 \mathrm{~b}$ & $5.3 \pm 0.6 \mathrm{~ns}$ & $7.8 \pm 0.5 b$ & $8.6 \pm 0.5 \mathrm{~ns}$ & $9.0 \pm 0.6 \mathrm{~ns}$ & $10.0 \pm 0.8 \mathrm{~ns}$ & $11.3 \pm 1.0 \mathrm{~ns}$ & $13.2 \pm 1.8 \mathrm{~ns}$ & $16.2 \pm 1.9 \mathrm{~ns}$ & $20.4 \pm 2.6 \mathrm{~ns}$ \\
\hline SPD99 & $3.4 \pm 0.3 \mathrm{ab}$ & $5.3 \pm 0.2 \mathrm{~ns}$ & $7.1 \pm 0.4 \mathrm{ab}$ & $8.7 \pm 0.5 \mathrm{~ns}$ & $10.3 \pm 0.7 \mathrm{~ns}$ & $11.4 \pm 0.9 \mathrm{~ns}$ & $14.9 \pm 1.3 \mathrm{~ns}$ & $18.7 \pm 1.6 \mathrm{~ns}$ & $23.7 \pm 2.2 \mathrm{~ns}$ & $29.8 \pm 3.2 \mathrm{~ns}$ \\
\hline
\end{tabular}

Means \pm standard error: values in the same column followed by different letters indicate significant differences among sites at $P<0.05$ using Tukey's test; ns: no significant differences.

soils, the upper layers may be strongly compressed. Thus, the heavy equipment used in the last 40 years at our study site has the potential to increase the severity of compaction from the surface to subsurface soils in moist soils (due to annual flooding) along riparian forest.

Soil penetration resistance at the depth of $90-100 \mathrm{~cm}$ in SPD99 shows the highest value with very strong resistance against the root penetration. Canarache [38] reported that soil penetration resistance value with more than $15.0 \mathrm{~J} \mathrm{~cm}^{-1}$ leads to critical root growth. Nevertheless, values of soil penetration resistance ranged from 2.6 to $10.0 \mathrm{~J} \mathrm{~cm}^{-1}$ may lead to some limitations for root growth. This was supported by Hattori et al. [6], stating that the value of soil penetration resistance exceeding $5.2 \mathrm{~J} \mathrm{~cm}^{-1}$ at $0-60 \mathrm{~cm}$ depth could lead to limitation of root growth in the compacted area. Soil penetration resistance values less than $5.2 \mathrm{~J} \mathrm{~cm}^{-1}$ indicated that the soils were undisturbed. Even if root development is altered by the changes in soil compactness, above-ground growth probably adapts, if the plant can obtain sufficient water and nutrient [31]. A comprehensive study by Hattori et al. [6] was carried out between soil penetration resistance in the compacted area and undisturbed area. The findings show the value of $6.8 \mathrm{~J} \mathrm{~cm}^{-1}$ and $14.5 \mathrm{~J} \mathrm{~cm}^{-1}$ for surface soils and subsurface soils, respectively, in the compacted area. Meanwhile, the value of soil penetration resistance in an undisturbed area had two to three times less than the compacted area [6]. Thus, the values obtained in our study site were mostly categorized as a compacted area in both surface and subsurface layers.

The average RLI of planted S. macrophylla ranged from $11.7 \%$ to $27.3 \%$ in SPD98 plot and SPD97 plot, respectively (Figure 5). The relationship between Dipterocarp tree species with relative light intensity had been reported in numerous studies and is reasonably well known [29, 39-41]. In the field trials, rates of Dipterocarp growth and survival for development of enrichment planting method are consistently better in moderate light levels under 30\% RLI than in high light levels more than 50\% RLI [28, 29, 42-44].

\subsection{Effects of Soil Compaction and Relative Light Intensity} on the Survival and Growth Performance. To clarify the importance of selected environmental factors in each of the four study sites, comparison was carried out to find out the relationship between soil penetration resistance and RLI on the survival and growth performance of S. macrophylla. Although growth parameter in terms of MAID showed 


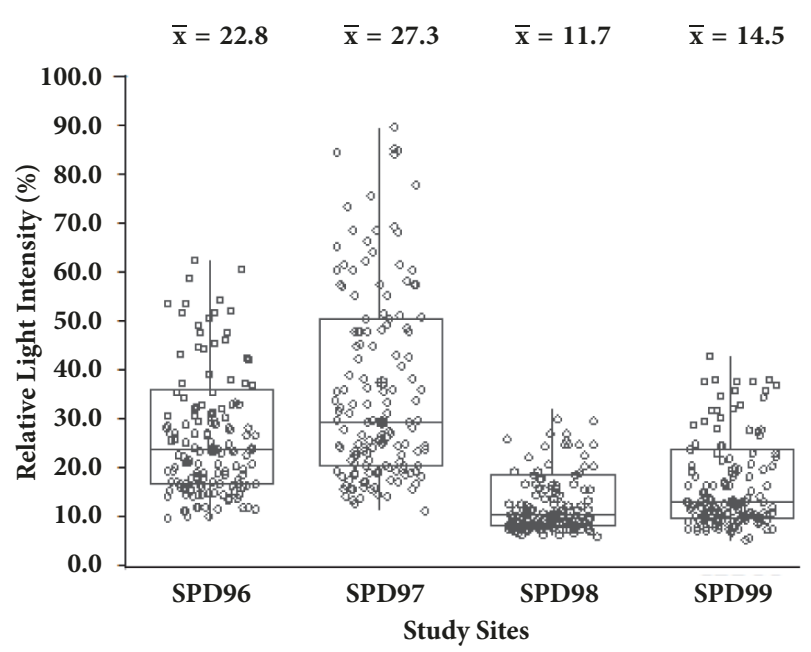

FIGURE 5: Boxplots: average relative light intensity of planted $S$. macrophylla in SPD96, SPD97, SPD98, and SPD99. The boxplots (box and whisker illustrations) display data on values of minimum, maximum, first quartile, third quartile, interquartile range, and median as shown in the figure above. $\bar{x}$ : mean value; $n$ : number of RLI measurements.

moderate positive correlation with surface soil penetration resistance, there was a poor correlation between survival and growth parameters (MAIH and MAIV) with RLI (Table 4). There were no correlations found between survival and soil penetration resistance although survival was higher in SPD96 followed by SPD97, SPD98, and SPD99. In this study, poor and negative correlation was also found for the soil penetration resistance of subsurface soils with survival, MAIH, MAID, and MAIV. Furthermore, there was no clear relationship between MAIH and MAIV with measured environmental factors although several studies have found positive and negative effects of environmental factors on various Dipterocarp trees across a broad range of MAIH and MAIV values $[6,45,46]$. Besides, no clear relationship was found between RLI with the survival of planted $S$. macrophylla.

However, there were moderate positive and negative correlations between MAID with soil penetration resistance in surface soils $(0-10 \mathrm{~cm}, 10-20 \mathrm{~cm}$, and $20-30 \mathrm{~cm}$ depths) and with RLI. MAID was enhanced by low soil penetration resistance and RLI in surface soils versus subsurface soils. Based on Figure 6, soil penetration resistance at surface soils decreased and RLI increased with an increased MAID in study sites. High light irradiance depicted an increase in MAID of planted S. macrophylla in SPD96 and SPD97 whereas low light irradiance portrays a decrease in MAID of planted S. macrophylla in SPD98 and SPD99. The RLI in SPD96 and SPD97 was significantly higher than in SPD98 and SPD99.

Soil compaction has profound effects on the success of subsequent forest reforestation because high compaction restricts the rooting area, decreases tree establishment, and decreases soil aeration $[6,9,47]$. Figure 6 shows low soil penetration resistance $(0-10 \mathrm{~cm}, 10-20 \mathrm{~cm}$, and $20-30 \mathrm{~cm}$ depths) in SPD96 and SPD97 since it was to be related to the productivity of trees and an increase in MAID. A high soil penetration resistance in SPD98 and SPD99 portrays a distribution with low MAID in contrast to a low soil penetration resistance which corresponds to those shown in Figure 6. Also, our previous study showed that the Soil Fertility Index (SFI) determines soil fertility status in relation to the productivity of planted $S$. macrophylla [11]. Our previous result revealed that there was a strong correlation between the soil available phosphorus content and the productivity of S. macrophylla, in which it was directly proportional to the average tree height, $\mathrm{DBH}$, and survival percentage of trees [11]. Many planting techniques have been used to ameliorate compacted soils and increase the survival of planted species $[15,48]$. These previous studies recommended line planting technique as one of the best techniques versus other techniques such as open planting, cluster planting, and island corridor planting scheme techniques for planting Dipterocarps $[15,48]$. In addition, Pamoengkas and Romell et al. $[49,50]$ mentioned that line planting technique can accelerate the growth performance of Dipterocarp species and consequently avoids high mortality of planted seedlings due to heat and water stress condition.

There was a significant correlation between RLI and MAID. SPD96 and SPD97 trees with higher light irradiance portray an increase in MAID of planted S. macrophylla as compared to SPD98 and SPD99 trees. The RLI in SPD96 and SPD97 was significantly higher than in SPD98 and SPD99 (Figure 6). High light irradiance resulted in better survival of planted S. macrophylla. Study sites in SPD96 and SPD97 were influenced by strong adaptability of planted trees in an ecosystem. Forest structural traits such as highest tree height and trunk diameter distribution varied between study plots. Highest average DBH was recorded in SPD97; meanwhile highest average tree height was depicted in SPD96. Average light irradiance for S. macrophylla ranged from $11.7 \%$ to $27.3 \%$ and this had contributed in terms of tree height and $\mathrm{DBH}$. This was supported by previous study that the Dipterocarp trees under 30\% RLI were better in height and diameter increment as well as leaf number increment than those under full sunlight [45]. In fact, adequate light irradiance makes energy available for plant photosynthesis to take place. Several researchers also reported $[6,14,51,52]$ that sunlight exposure enhanced the growth performance of Dipterocarp species under suitable planting conditions.

\section{Conclusions and Recommendations}

In conclusion, assessment on the survival and growth performance of planted S. macrophylla under various age stands had been carried out at Sampadi Forest Reserve. The planted S. macrophylla at reforestation sites were able to survive in high compacted soils along the streams and rivers. In this study, rehabilitation efforts of enrichment planting was demonstrated to be a suitable approach due to the total percentage of survived trees which achieved more than $50 \%$ of survival in the experimental plots. Generally, different soil compaction status within study plots had influenced the 

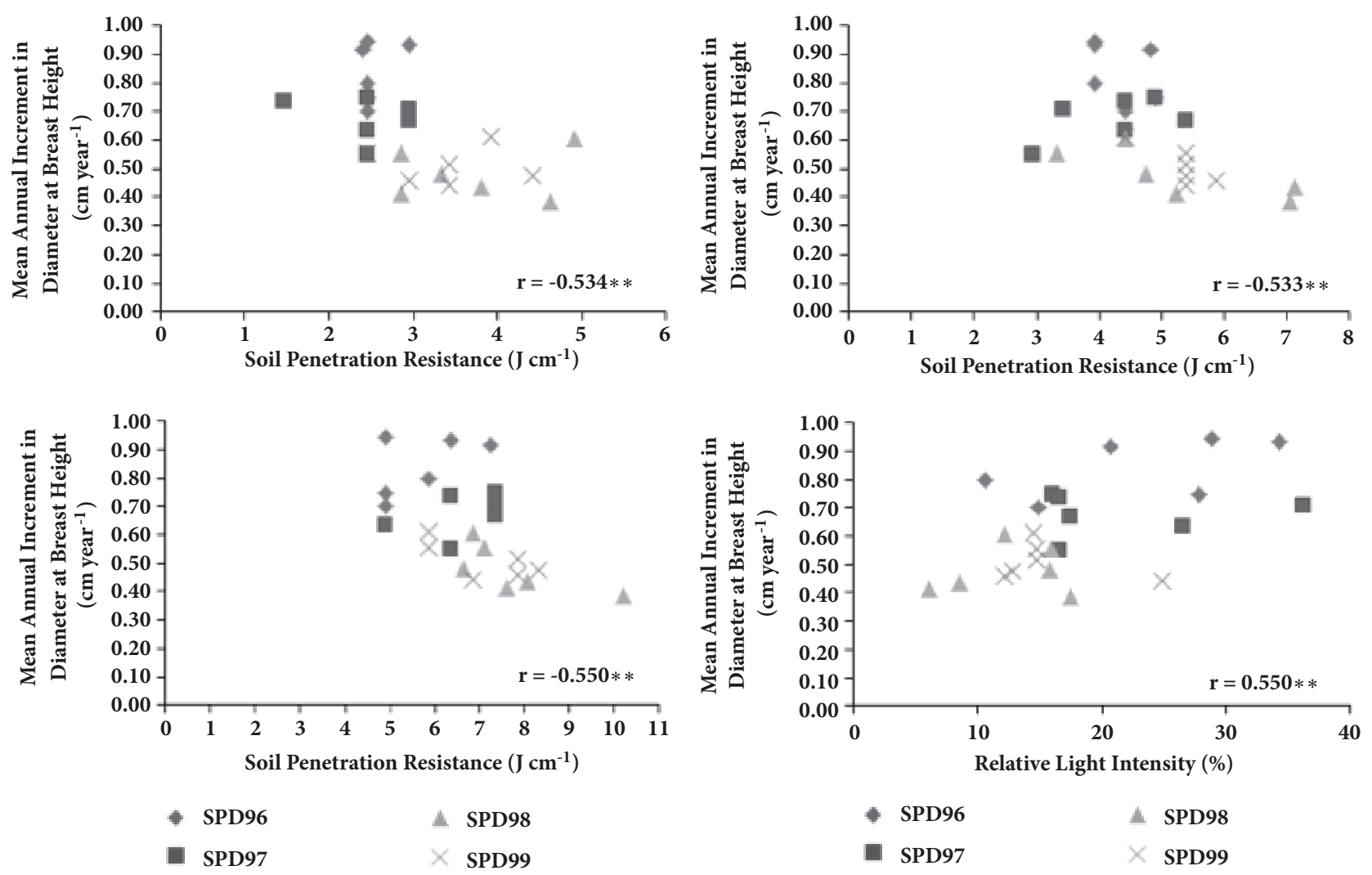

FIGURE 6: Relationship between mean annual increment in diameter at breast height with soil penetration resistance and relative light intensity. **: correlation is significant at $P<0.01$, using Pearson correlation matrix.

TABLE 4: Stepwise multiple regression analysis on the survival and tree growth parameters (MAIH, MAID, and MAIV) in relation to explanatory environmental factors (soil compaction and relative light intensity).

\begin{tabular}{|c|c|c|c|c|c|c|c|}
\hline & \multirow[b]{3}{*}{ Depth } & \multicolumn{6}{|c|}{ Explanatory Variables } \\
\hline & & \multicolumn{4}{|c|}{ Soil Penetration Resistance } & \multirow{2}{*}{ Relative Light Intensity } & \multirow{2}{*}{ Adjusted $\mathrm{R}^{2}$} \\
\hline & & $0-10 \mathrm{~cm}$ & $10-20 \mathrm{~cm}$ & $20-30 \mathrm{~cm}$ & $30-40 \mathrm{~cm}$ & & \\
\hline \multirow{4}{*}{ Dependent Variables } & Survival & -0.352 & -0.360 & -0.291 & -0.238 & 0.359 & - \\
\hline & MAIH & -0.372 & -0.250 & -0.222 & 0.031 & 0.375 & - \\
\hline & MAID & $-0.534 * *$ & $-0.533 * *$ & $-0.550 * *$ & -0.340 & $0.550 * *$ & 0.424 \\
\hline & MAIV & 0.266 & -0.200 & -0.178 & -0.184 & 0.170 & - \\
\hline
\end{tabular}

MAIH, mean annual increment in height; MAID, mean annual increment in diameter; MAIV, mean annual increment in volume.

Standardized regression coefficients, significant level, and adjusted $\mathrm{R}^{2}$ values are given. $\mathrm{n}=24$. $* *$ : correlation is significant at $P<0.01$, using Pearson correlation matrix. Unsuitable explanatory variables were excluded by the stepwise procedure.

survival and growth performance of planted S. macrophylla in the reforestation sites. Based on the results, the soil penetration resistance in SPD98 and SPD99 at surface soils was higher as compared to SPD96 and SPD97 study plots.

Further detailed ecological studies in future should be implemented for more comparisons between the survival and growth performance of S. macrophylla affected by other environmental factors such as weed competition, microclimate, and soil biological properties. The composition and structure of existing natural pioneer species that interact and compete to obtain light, space, and nutrient with the planted trees should be identified clearly. The plot health test before planting trees and early stage of experimental reforestation are recommended in the future so as to obtain the initial data of seedling growth prior to nursery and field planting. In addition, long-term monitoring period of growth performance and canopy structure should be implemented to draw up a Dipterocarp planting scheme for reforestation purpose in riparian ecosystem.

\section{Data Availability}

The data used to support the findings of this study are available from the corresponding author upon request. 


\section{Disclosure}

The research project was conducted under supervision of Dr. Mohd Effendi Wasli and the project was run as Aina Nadia Najwa Binti Mohamad Jaffar's research project.

\section{Conflicts of Interest}

The authors declare that there are no conflicts of interest regarding the publication of this paper.

\section{Acknowledgments}

This research was part of the Final Year Project Dissertation by Aina Nadia Najwa Mohamad Jaffar under the supervision of Dr. Mohd Effendi Wasli and was financially supported by the following grant entities: Fundamental Research Grant Scheme (FRGS (E14099/F07/69/989/2013(30)) from Ministry of Higher Education, Malaysia, and a Universiti Malaysia Sarawak (UNIMAS) internal grant under the Ph.D. Student Fund (F07/DPP56/1353/2016/3) and Grant-in-Aid for scientific research purpose by the Japan-Malaysia Association (JMA) and NPO Rainforest Sarawak. Authors wish to express gratitude to the Director and staff of the Forest Department, Sarawak, for their supportive assistance during the duration of this study. Authors would also like to extend thanks to local villagers from the study area for their kind cooperation and assistance during the field survey. Aina Nadia Najwa Mohamad Jaffar has the following similar Unpublished Final Year Project Dissertation: A. N. N. M. Jaffar, 2017, Effect of Environmental Factors on the Growth and Survivability of Planted Shorea macrophylla along Riverbanks Batang Kayan Ulu, Lundu, Sarawak, Universiti Malaysia Sarawak, Kota Samarahan, Sarawak, Malaysia.

\section{References}

[1] D. P. Edwards, T. H. Larsen, T. D. Docherty et al., "Degraded lands worth protecting: the biological importance of Southeast Asia's repeatedly logged forests," Proceedings of the Royal Society B, vol. 278, no. 1702, pp. 82-90, 2010.

[2] L. R. Heaney, "A synopsis of climatic and vegetational change in Southeast Asia," Climatic Change, vol. 19, no. 1-2, pp. 53-61, 1991.

[3] R. J. Gregg and A. Porges, Forest Governance, Markets and Trade: Implications for Sustainability and Livelihoods, Forest Trends and Sidley Austin, United Stated, 2008.

[4] S. Appanah and G. Weinland, "Experience with planting Dipterocarps in Peninsular Malaysia," in Dipterocarp Forest Ecosystems: Towards Sustainable Management, A. Schulte and D. SchÖne, Eds., pp. 411-445, World Scientific Singapore, 1996.

[5] M. S. Safa, Z. Ibrahim, and A. Abdu, Potentialities of new line planting technique of enrichment planting in Peninsular Malaysia: A review of resource sustainability and economic feasibility, Universiti Putra Malaysia (UPM), Malaysia, 2004.

[6] D. Hattori, T. Kenzo, K. O. Irino, J. J. Kendawang, I. Ninomiya, and K. Sakurai, "Effects of soil compaction on the growth and mortality of planted Dipterocarp seedlings in a logged-over tropical rainforest in Sarawak, Malaysia," Forest Ecology and Management, vol. 310, pp. 770-776, 2013.
[7] C. Dinis, P. Surový, N. Ribeiro, and M. R. G. Oliveira, "The effect of soil compaction at different depths on cork oak seedling growth," New Forests, vol. 46, no. 2, pp. 235-246, 2014.

[8] J. Dawson, Flood-tolerant trees in the Urban Sphere, International Society of Arboriculture, United State, 2014.

[9] J. Letey, "Relationship between soil physical properties and crop production," Advances in Soil Science, vol. 1, pp. 277-294, 1985.

[10] M. Perumal, M. E. Wasli, S. Y. Ho, J. Lat, and H. Sani, "Survivorship and growth performance of Shorea macrophylla (de Vriese) after enrichment planting for reforestation purpose at Sarawak, Malaysia," OnLine Journal of Biological Sciences, vol. 17, no. 1, pp. 7-17, 2017.

[11] M. Perumal, M. E. Wasli, S. Y. Ho, J. Lat, and H. Sani, "Association between soil fertility and growth performance of planted Shorea macrophylla (de Vriese) after enrichment planting at rehabilitation sites of Sampadi Forest Reserve, Sarawak, Malaysia," International Journal of Forestry Research, vol. 2017, 2017.

[12] M. Nik Muhamad, H. Azizah, and A. Idris, "Rehabilitation of ex-tin mining land by agroforestry practice," Journal of Tropical Forest Science, vol. 71, pp. 123-127, 1994.

[13] S. McNamara, D. V. Tinh, P. D. Erskine, D. Lamb, D. Yates, and S. Brown, "Rehabilitating degraded forest land in central Vietnam with mixed native species plantings," Forest Ecology and Management, vol. 233, no. 2-3, pp. 358-365, 2006.

[14] H. Daisuke, K. Tanaka, K. Joseph Jawa, N. Ikuo, and S. Katsutoshi, "Rehabilitation of degraded tropical rainforest using Dipterocarp trees in Sarawak, Malaysia," International Journal of Forestry Research, vol. 2013, Article ID 683017, 11 pages, 2013.

[15] M. E. Wasli, H. Sani, S. Y. Ho et al., "Preliminary assessment on the growth performance of Dryobalanops beccarii dyer planted under enrichment planting technique at Gunung Apeng Forest Reserve," Kuroshio Science, vol. 8, pp. 45-52, 2014.

[16] K. Sakurai, I. Nimoniya, K. Harada, J. J. Kendawang, H. S. Lee, and K. Ogino, "Tree planting as ecosystem initiation on land degraded by shifting cultivation at the Bakam Experinmental Reserve, Sarawak," in Proceedings of the Workshop on Forest Ecosystem Rehabilitation, pp. 5-17, 1999.

[17] A. Shaliha Jamaluddin, A. Abdu, H. Abdul-Hamid et al., "Assessing soil fertility status of rehabilitated degraded tropical rainforest," American Journal of Environmental Sciences, vol. 9, no. 3, pp. 280-291, 2013.

[18] D. Hattori, T. Kenzo, J. J. Kendawang et al., "Effects of light intensity and soil physico-chemical properties on seedling mortality and growth of six Dipterocarp species planted for rehabilitation of degraded grassland, secondary forest and logged forest in Sarawak, Malaysia," Japanese Journal of Forest Environment, vol. 51, no. 2, pp. 105-115, 2009.

[19] Department of Agriculture, Types of Soil Data 2016, Department of Agriculture, Sarawak, Kuching, Malaysia, 2016.

[20] M. Perumal, M. E. Wasli, S. Y. Ho, J. Lat, and H. Sani, "Soil morphological and physicochemical properties at reforestation sites after enrichment planting of Shorea macrophylla in Sampadi Forest Reserve, Sarawak, Malaysia," Borneo Journal of Resource Science and Technology, vol. 5, no. 2, pp. 28-43, 2015.

[21] Hydrological Year Book Department, Irrigation and Drainage 2001-2010, Department of Irrigation and Drainage, Kuching, Sarawak, 2010

[22] Meteorological Department, Weather Data (Air Temperature) 2001-2010, Meteorological Department Sarawak, Kuching, Sarawak 2010. 
[23] X. Peng, L. L. Ye, C. H. Wang, H. Zhou, and B. Sun, “Temperature- and duration-dependent rice straw-derived biochar: Characteristics and its effects on soil properties of an Ultisol in Southern China," Soil and Tillage Research, vol. 112, no. 2, pp. 159-166, 2011.

[24] Forest Department Sarawak, "Planted Forests in Sarawak," in Proceedings of the International Conference, pp. 16-17, Sarawak, Malaysia, February 1998.

[25] M. Asaoka and N. Masaoka, Analysis of Heterogeneous Hydrological Properties of a Mountainous Hillslope Based on Intensive Observations, Graduate School of Agriculture, Kyoto University, Japan, 2012.

[26] K. Sakurai, B. Puriyakorn, P. Preechapanya, V. Tanpibal, K. Muangnil, and B. Prachaiyo, "Improvement of biological productivity in degraded lands in Thailand III. Soil hardness measurement in the field," Tropics, vol. 4, no. 2/3, pp. 151-172, 1995.

[27] D. Hattori, T. Kenzo, N. Yamauchi et al., "Effects of environmental factors on growth and mortality of Parashorea macrophylla (Dipterocarpaceae) planted on slopes and valleys in a degraded tropical secondary forest in Sarawak, Malaysia," Soil Science and Plant Nutrition, vol. 59, no. 2, pp. 218-228, 2013.

[28] G. Ådjers, S. Hadengganan, J. Kuusipalo, K. Nuryanto, and L. Vesa, "Enrichment planting of Dipterocarps in logged-over secondary forests: Effect of width, direction and maintenance method of planting line on selected Shorea species," Forest Ecology and Management, vol. 73, no. 1-3, pp. 259-270, 1995.

[29] L. H. Ang, "Effects of open and under planting on early survival and growth of Endospermum malaccense (Sesendok), Alstonia angustiloba (Pulai) and Shorea parvifolia (Meranti Sarang Punai)," Journal of Tropical Forest Sci, vol. 3, pp. 380384, 1991.

[30] R. J. Kueh, N. M. Majid, O. H. Ahmed, and S. Gandaseca, "Assessment of carbon stock in chronosequence rehabilitated tropical forest stands in Malaysia," Journal of Forest and Environmental Science (JFES), vol. 32, no. 3, pp. 302-310, 2016.

[31] A. P. Whitmore and W. R. Whalley, "Physical effects of soil drying on roots and crop growth," Journal of Experimental Botany, vol. 60, no. 10, pp. 2845-2857, 2009.

[32] Environmental Impact Assessment for the proposed forest plantation under LPF/0042 at the Sampadi Area LPF/0042. Malaysia: Sampadi Area, Kuching Division; Natural Resource and Environment Board, Sarawak, 2010.

[33] E. Greacen and R. Sands, "Compaction of forest soils: A review," Australian Journal of Soil Research, vol. 18, no. 2, pp. 163-189, 1980.

[34] J. Lipiec and W. Stepniewski, "Effects of soil compaction and tillage systems on uptake and losses of nutrients," Soil and Tillage Research, vol. 35, no. 1-2, pp. 37-52, 1995.

[35] S. J. Wright, "Tropical forests in a changing environment," Trends in Ecology and Evolution, vol. 20, no. 10, pp. 553-560, 2005.

[36] M. Perumal, M. E. Wasli, and J. Lat, "Estimating soil fertility status using soil quality indices at reforestation sites in Sampadi Forest Reserve, Sarawak, Malaysia," in Proceedings of the 2nd Regional Taxonomy and Ecology Conference, I. Jusoh, I. Ipor, A. S. A. Puad, and., and R. Hassan, Eds., pp. 275-287, Universiti Malaysia Sarawak, Sarawak, Malaysia, 2016.

[37] T. Batey, "Soil compaction and soil management: A review," Soil Use and Management, vol. 25, no. 4, pp. 335-345, 2009.
[38] A. P. Canarache, "PENETR—a generalized semi-empirical model estimating soil resistance to penetration," Soil and Tillage Research, vol. 16, no. 1-2, pp. 51-70, 1990.

[39] G. Ådjers, J. Kuusipalo, S. Hadengganan, K. Nuryanto, and L. Vesa, "Performance of ten Dipterocarp species in restocking logged-over forest areas subjected to shifting cultivation," Journal of Tropical Forest Science, vol. 9, no. 2, pp. 151-160, 1996.

[40] A. Itoh, T. Yamakura, and H. S. Le, "Effects of light intensity on the growth and allometry of two bornean Dryobalanops (Dipterocarpaceae) seedlings," Journal of Tropical Forest Science, vol. 11, no. 3, pp. 610-618, 1999.

[41] W. Schwarzwaller, F. Y. C. Chai, and B. Hahn-Schilling, "Growth characteristics and response to illumination of some Shorea species in the logged-over mixed Dipterocarp forest of Sarawak, Malaysia," Journal of Tropical Forest Science, vol. 11, no. 3, pp. 554-569, 1999.

[42] M. S. Ashton, B. M. P. Singhakumara, and H. K. Gamage, Interaction between light and drought affect performance of Asian tropical tree species that have differing topographic affinities, Department of Forestry Environmental Science, University of Sri Jayewardenepura, Sri Lanka, 2006.

[43] R. S. Raja Barizan, "Growth and survival of planted seedlings of Hopea odorata under different light conditions and fertilizer levels in a logged-over forest," in Proceedings of the Fifth RoundTable Conference on Dipterocarps, S. Appanah and K. C. Khoo, Eds., pp. 180-188, Forest Research Institute of Malaysia, Chiang Mai, Thailand, 1996.

[44] R. S. Raja Barizan and S. Appanah, "Phosphorus fertilizer boosts growth of out-planted Dipterocarp seedlings," in Proceedings of the Conference on Forestry and Forest Product Research, S. Appanah, Y. M. Y. Safiah, W. J. Astinah, and K. C. Khoo, Eds., pp. 96-110, Forest Research Institute of Malaysia, Kuala Lumpur, Malaysia, 1997.

[45] O. H. Sherzad, H. Mohd Zaki, A. H. Hazandy, A. Mohamad Azani, and W. D. Noordin, "Growth and physiological responses of Shorea materialis ridl. seedlings to various light regimes and fertilizer levels under nursery condition," Malaysian Forester, vol. 78, no. 1-2, pp. 133-150, 2015.

[46] A. Arifin, S. Tanaka, S. Jusop, N. M. Majid, Z. Ibrahim, and K. Sakurai, "Rehabilitation of degraded tropical rainforest in Peninsular Malaysia with a multi-storied plantation technique of indigenous Dipterocarp species," Japanese Journal of Forest Environment, vol. 50, no. 2, pp. 141-152, 2008.

[47] D. C. Kim, Soil Compaction and trees: Causes, symptoms and effects, University of Georgia School of Forest Resources Extension Publication, United State, 2000.

[48] K. Ogino, H. S. Lee, and J. J. Kendawang, in Proceedings of the Workshop on Forest Ecosystem Rehabilitation, Forest Department, Sarawak, Malaysia, 2000.

[49] P. Pamoengkas, "Potentialities of line planting technique in rehabilitation of logged-over area referred to species diversity, growth and soil quality," Biodiversitas, Journal of Biological Diversity, vol. 11, no. 1, pp. 34-39, 2010.

[50] E. Romell, G. Hallsby, A. Karlsson, and C. Garcia, "Artificial canopy gaps in a Macaranga spp. dominated secondary tropical rain forest-Effects on survival and above ground increment of four under-planted Dipterocarp species," Forest Ecology and Management, vol. 255, no. 5-6, pp. 1452-1460, 2008.

[51] D. I. Nicholson, "Light requirements of seedlings of five species of Dipterocarpaceae," Malaysian Forester, vol. 23, pp. 344-356, 1960. 
[52] T. Kenzo, R. Yoneda, Y. Matsumoto, A. Mohamad Azani, and M. Nik Majid, "Growth and photosynthetic response of four Malaysian indigenous tree species under different light conditions," Journal of Tropical Forest Science, vol. 23, no. 3, pp. 271281, 2011. 

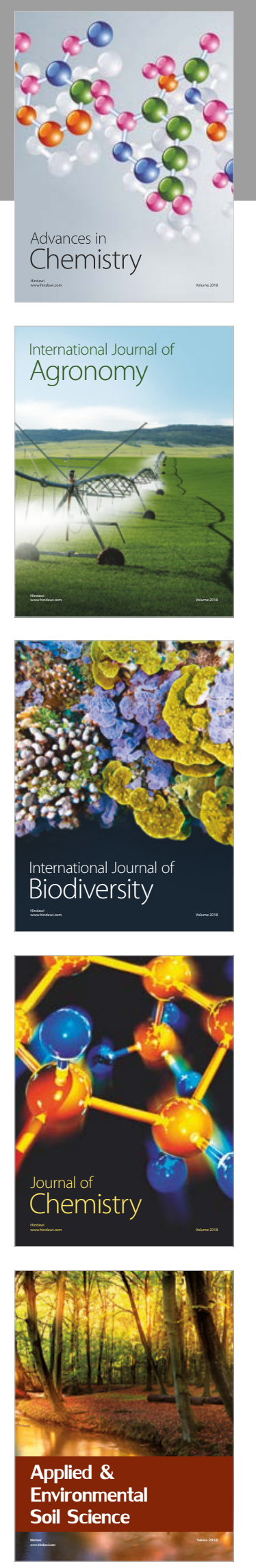

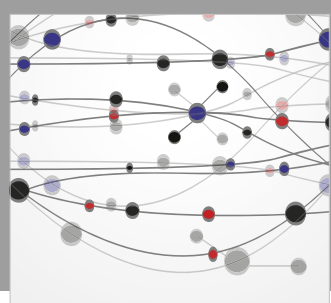

The Scientific World Journal

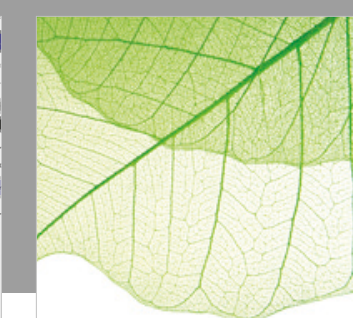

Journal of Botany

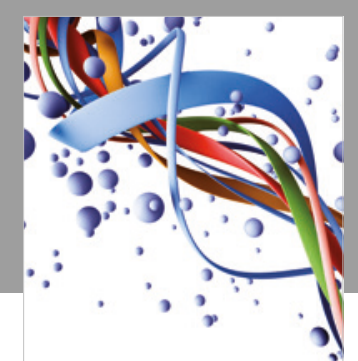

Scientifica

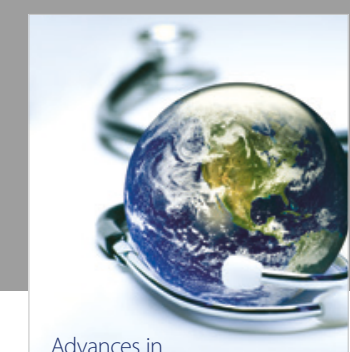

Public Health

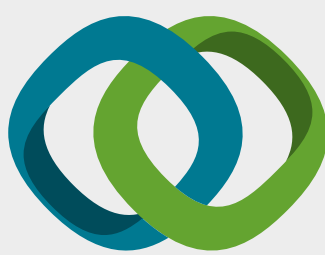

Hindawi

Submit your manuscripts at

www.hindawi.com
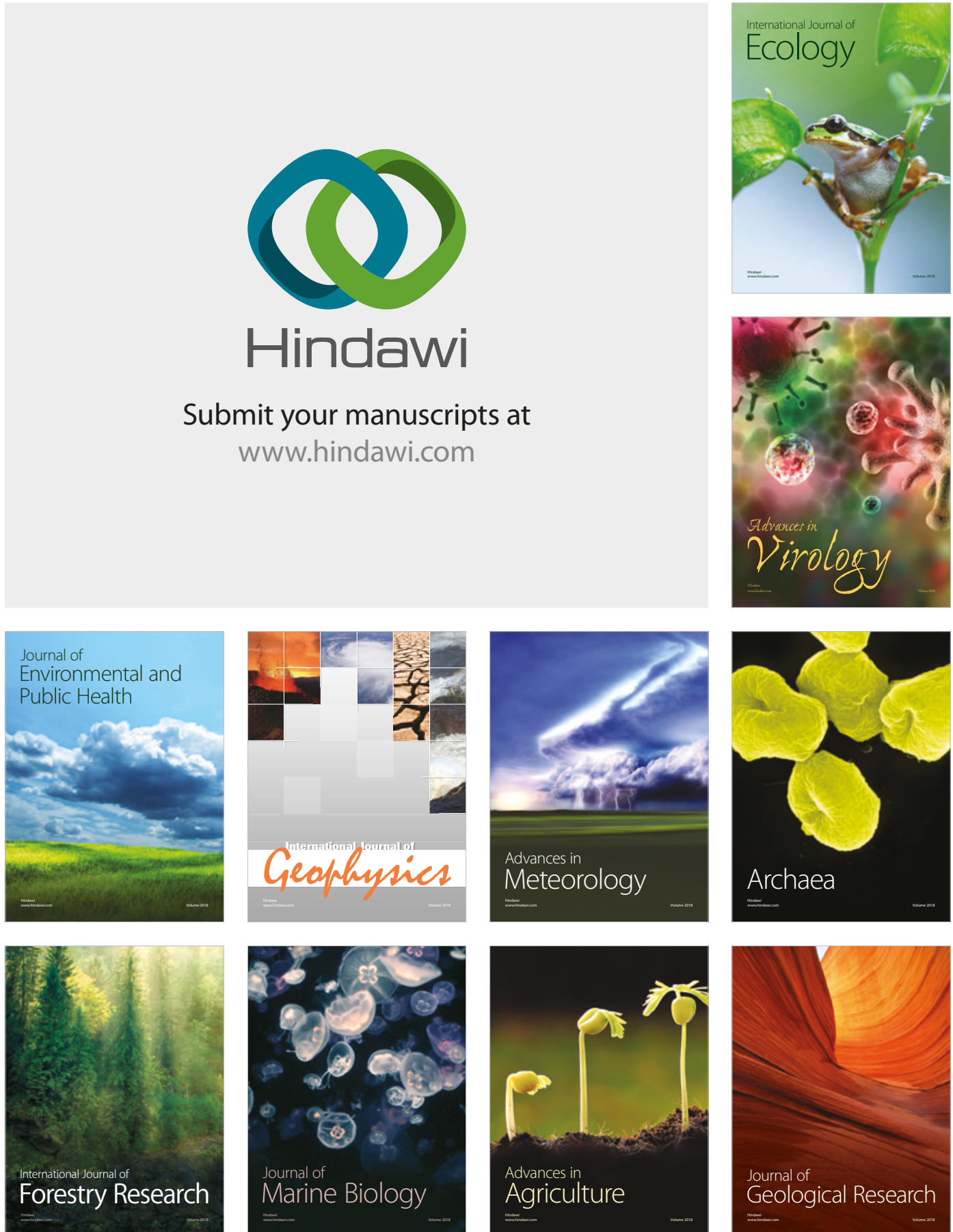

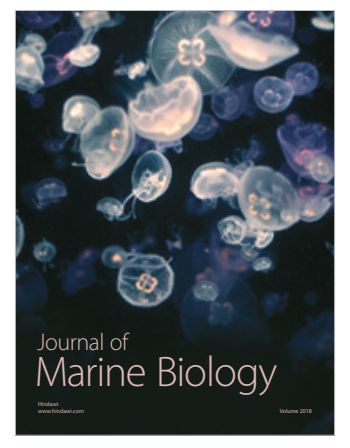

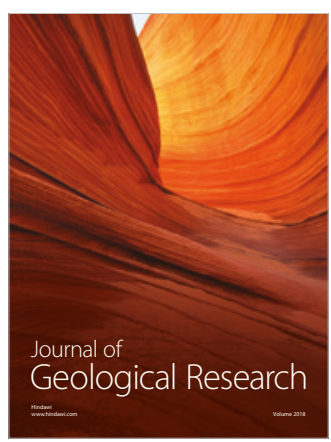

